\title{
DOLICHODERUS TASCHENBERGI MAYR (HYMENOPTERA: FORMICIDAE) FROM AN EARLY HOLOCENE FOSSIL INSECT ASSEMBLAGE IN THE COLORADO FRONT RANGE
}

\author{
By Andre Francoeur* and Scott A. Elias $\dagger$
}

A paleoenvironmental study of Holocene (Post-glacial) age sites in the Front Range of the Colorado Rocky Mountains was begun in 1981 , with the excavation of organic detrital sediments from a deltaic deposit at the point where South St. Vrain Creek enters Lake Isabelle (Fig. 1). The study site lies in the ecotone between the subalpine forest and alpine tundra, and the insect faunal assemblages from the site consistently reflect past environments that fall within the same zone. Sediments ranging in age from 9000 to 7900 years before present (yr. BP) were analyzed for insect fossils, and yielded a total of 138 taxa, dominated by Coleoptera (Elias, 1985). A head capsule of a gynomorph of the ant Dolichoderus taschenbergi Mayr was recovered from an interval correlated with a radiocarbon age of $7900 \mathrm{yr}$. BP (Fig. 2). Other ant taxa from this time interval include Camponotus cf. herculeanus L., Formica neorufibarbis Emery and Myrmica sp., all of which may be found in the forest-tundra ecotonal regions of the Front Range today. In general, fossil insect assemblages from this and other high altitude sites in the Colorado Rockies suggest that the time interval associated with these ant fossils falls approximately in the middle of a two thousand year climatic optimum, in which altitudinal tree limit was at least as high as it is today (Elias, 1983, 1985).

The recovered fossil head capsule of Dolichoderus agrees obviously with recent specimens of taschenbergi Mayr (Fig. 3.). Such characters as the habitus of the capsule, the position, size and shape of the eyes, the diverging and widely separated frontal carinae, the flanges overhanging in part the antennal sockets, the sinuous anterior margin of clypeus, the absence of sculpture on the

\footnotetext{
*Pure Sciences Department, University of Quebec at Chicoutimi, 555, boulevard de I'Université, Chicoutimi, Québec, Canada, G7H 2B1

†Institute of Arctic and Alpine Research, Campus Box 450, University of Colorado, Boulder, Colorado, 80309, USA

Manuscript received by the editor October 10, 1984
} 


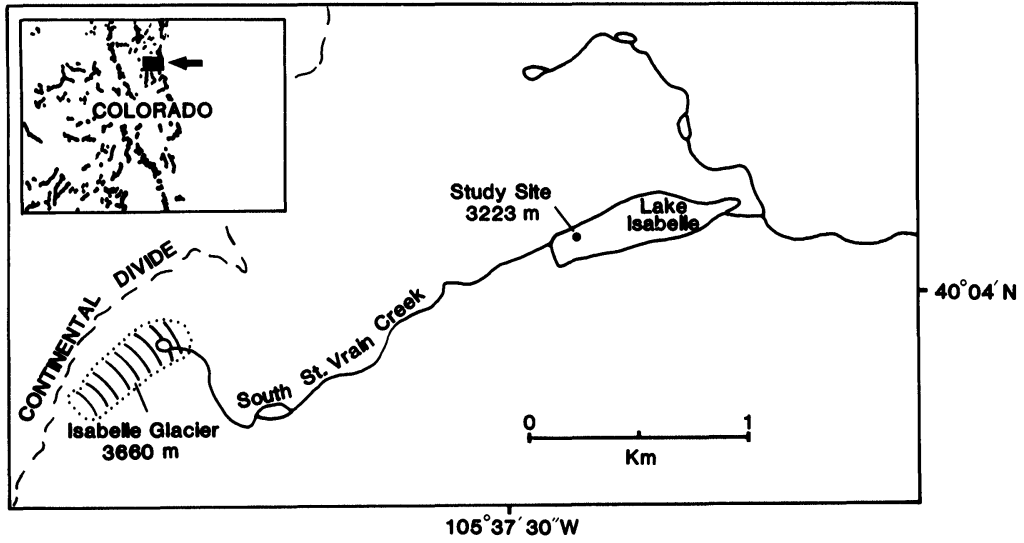

Figure 1. Map of fossil locality near Lake Isabelle, Colorado Front Range.

posterior half of head, and the blackish coloration are strongly congruent. Though partly obscured punctures, foveolae and faint striations are visible on genae and clypeus; the amount of sculptures varies on these parts in recent specimens. The presence of three ocelli identifies a gynomorph.

In the Nearctic region, the four representatives of the ant genus Dolichoderus belonging to the subgenus Hypoclinea are found only in the eastern half of the continent, from southern Canada to the Gulf States in U.S. (Smith, 1979). They are mainly associated with the deciduous forest biome and the transition zones with the boreal coniferous forest. The known range of $D$. taschenbergi covers the northern half of that territory with sporadic occurrences in the west from southern Manitoba to South Dakota. One might predict the rare occurrence of this insect in northern Colorado, but it is not reported there by Gregg (1963). He considers the genus as extinct in that state and concludes that it was an element of the Pre-glacial tertiary ant fauna. The discovery of the fossil head of Post-glacial age suggests a rather recent extinction from Colorado, if at all.

As noted in the discussion of fossil beetle taxa from the Lake Isabelle sites (Elias, 1985), it appears certain that a considerable percentage of the winged insects preserved in high altitude fossilbearing deposits are derived from downslope regions, and were carried upslope by mind currents. The fossil specimen of the ant $D$. taschenbergi was probably deposited in the Lake Isabelle basin after 


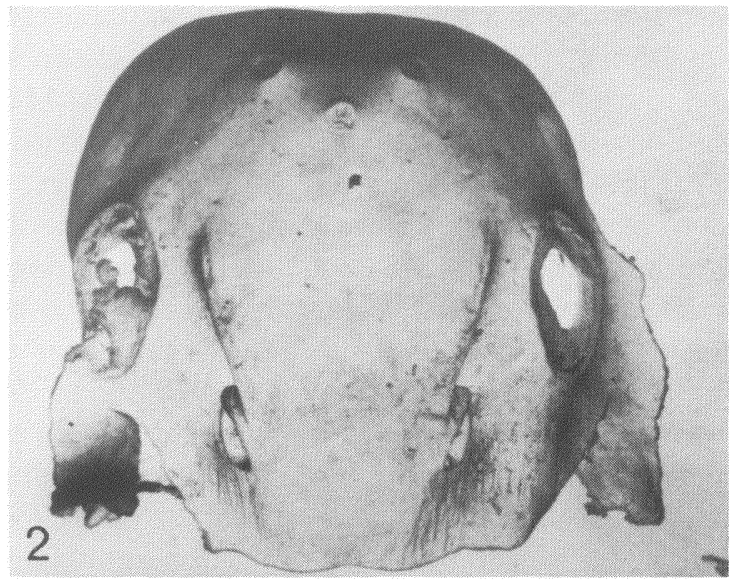

Figure 2. Fossil head capsule of a gynomorph of Dolichoderus taschenbergi, recovered from a layer correlated with a radiocarbon age of $7900 \mathrm{yr}$. BP. The voucher specimen is deposited in the Institute of Arctic and Alpine Research Quaternary Entomology Collection, University of Colorado.

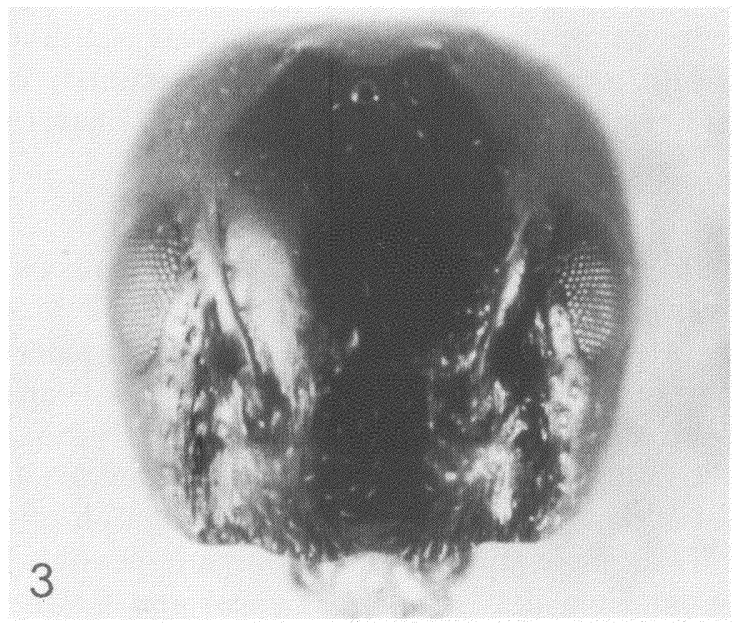

Figure 3. Head capsule of a gynomorph of Dolichoderus taschenbergi, collected on a sandy ground after nuptial flight in Port Kent, Clinton, Co., New York, 1965-VII-02, AF-04783. 
being carried upslope in a nuptial flight. The actual location of the mother colony was probably some tens of kilometers downslope, in the grassland-lower montane transition zone (sensu Marr, 1967), where deciduous trees are mixed with pines. The altitude of this zone ranges from 1700 to $1825 \mathrm{~m}$ as in the Front Range.

Colonies of $D$. taschenbergi, consisting of thousands of individuals, prefer to build their nests in sandy soil of partly open wooded areas or at the edge of woods. The entrance is usually covered with a low mound of thatch composed of either grass, twigs or needles (Creighton 1950, Smith 1979, Wheeler and Wheeler 1963). Such nests were observed in Quebec in mixed hardwoods with pines either on rocky grounds or on morainic and fluviatile sand deposits (Francoeur, unpublished data). Workers forage in typical files and actively collect sugary secretions of coccids and aphids on trees and bushes, or scavenge dead arthropods. Bradley and Hinks (1968) reported this ant attending aphids on jack pine in Manitoba.

These ecological and ethological traits were likely the same at the time when the reported fossil was living. At about $8000 \mathrm{yr}$. BP, altitudinal tree limit has apparently already reached the Lake Isabelle cirque basin, subsequent to deglaciation. The faunal evidence from insect fossil assemblages of this age from the Colorado Front Range suggests that climatic amelioration was well underway by this time, with mean July temperatures (an estimate of summer warmth) as warm or warmer than modern values (Elias, 1983, 1985).

\section{ACKNOWLDGEMENTS}

We wish to thank Dr. W.M. Briggs for preparing the scanning electron micrograph of the fossil specimen and Dr. F.M. Carpenter for making a reverse lighting print. Funding for paleoecological research at Lake Isabelle was provided by a U.S. National Park Service Contract, \#CX-1200-2-B048, and by a National Science Foundation, Long-Term Ecological Research Grant, BSR-8012095. Mr. R. Loiselle mounted and took the micrograph of the recent specimen. Taxonomic study of ants was made possible through a research grant from the National Sciences and Engineering Research Council of Canada. 


\section{REFERENCES}

Bradley, G. A. AND J. D. Hinks.

1968. Ants, Aphids and jack pine in Manitoba. Can. Ent. 100(1):40-50.

Creighton, W. S.

1950. The ants of North America. Bull. Mus. Comp. Zool. Harvard, 104:1-585.

Elias, S. A.

1983. Paleoenvironmental interpretations of Holocene insect fossil assemblages from the La Poudre Pass site, northern Colorado Front Range. Palaeogeography, Palaeoclimatology, Palaeoecology, 41:87-102.

1985. Paleoenvironmental interpretations of Holocene insect fossil assemblages from four high altitude sites in the Colorado Front Range. Arctic and Alpine Research, 17:31-48.

GREGG, R. E.

1963. The Ants of Colorado. University of Colorado Press, Boulder, $722 \mathrm{pp}$. MARR, J. W.

1967. Ecosystems of the east slope of the Front Range in Colorado. UniverSMITH, D. R. sity of Colorado Studies, Series in Biology, No. 8. 134 pp.

1979. Formicidae. In Krombein, K.V. et al. Catalogue of Hymenoptera in America north of Mexico. Vol. 2, pp. 1323-1522. Smithsonian Institution Press, Washington, D.C.

WheELeR, G. C. AND J. Wheeler.

1963. The ants of North Dakota. University of North Dakota Press, Grand Forks. 326 p. 

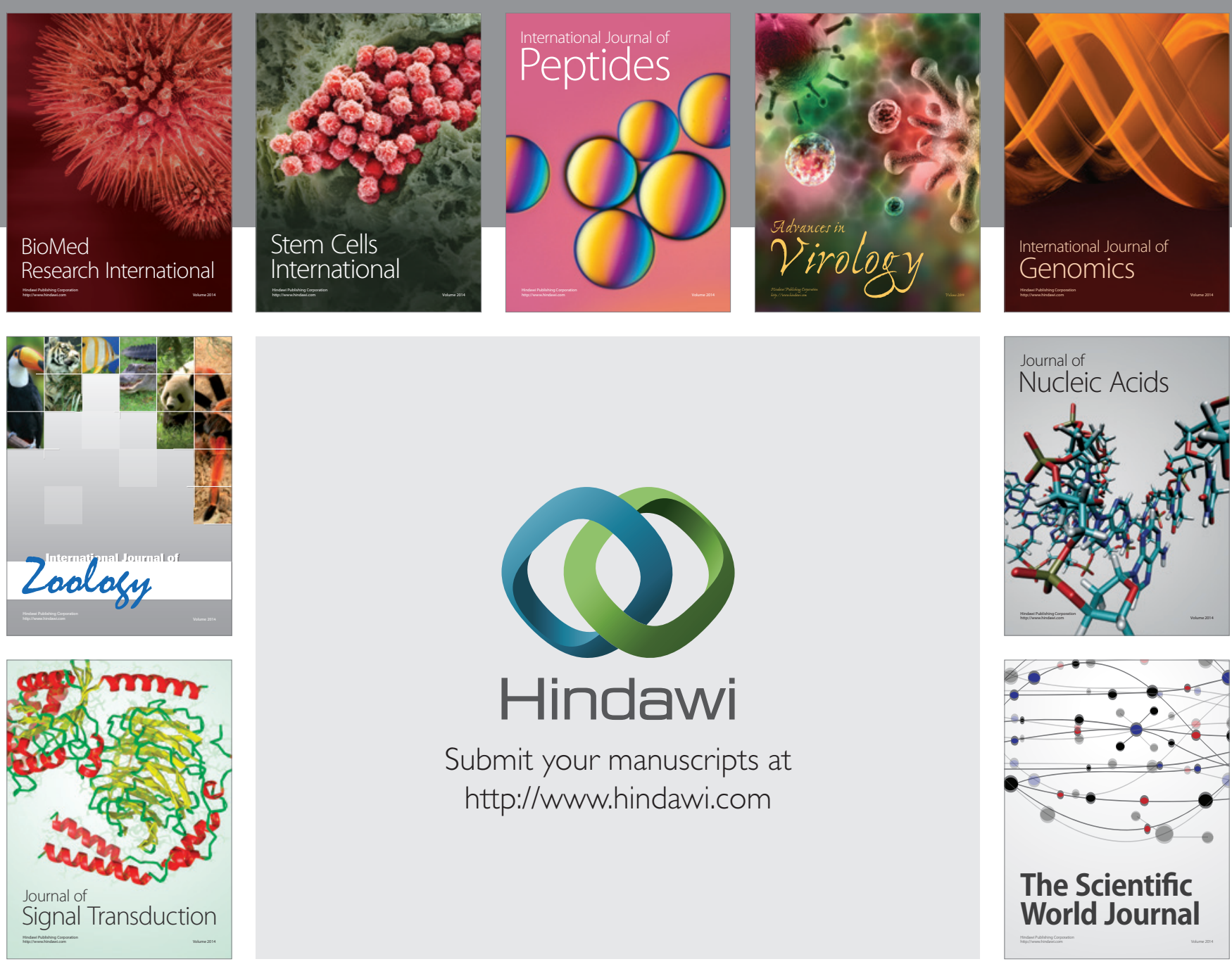

Submit your manuscripts at

http://www.hindawi.com
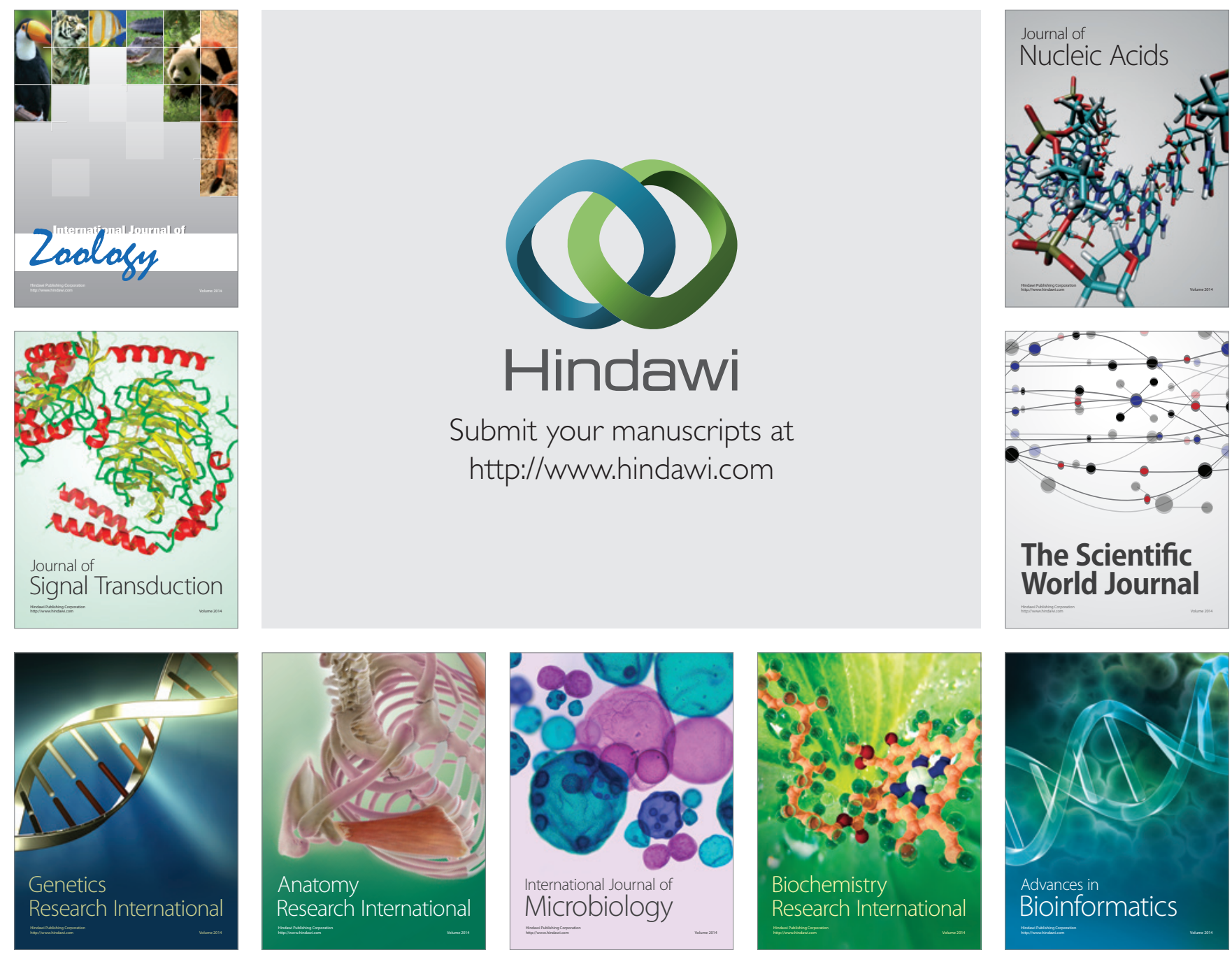

The Scientific World Journal
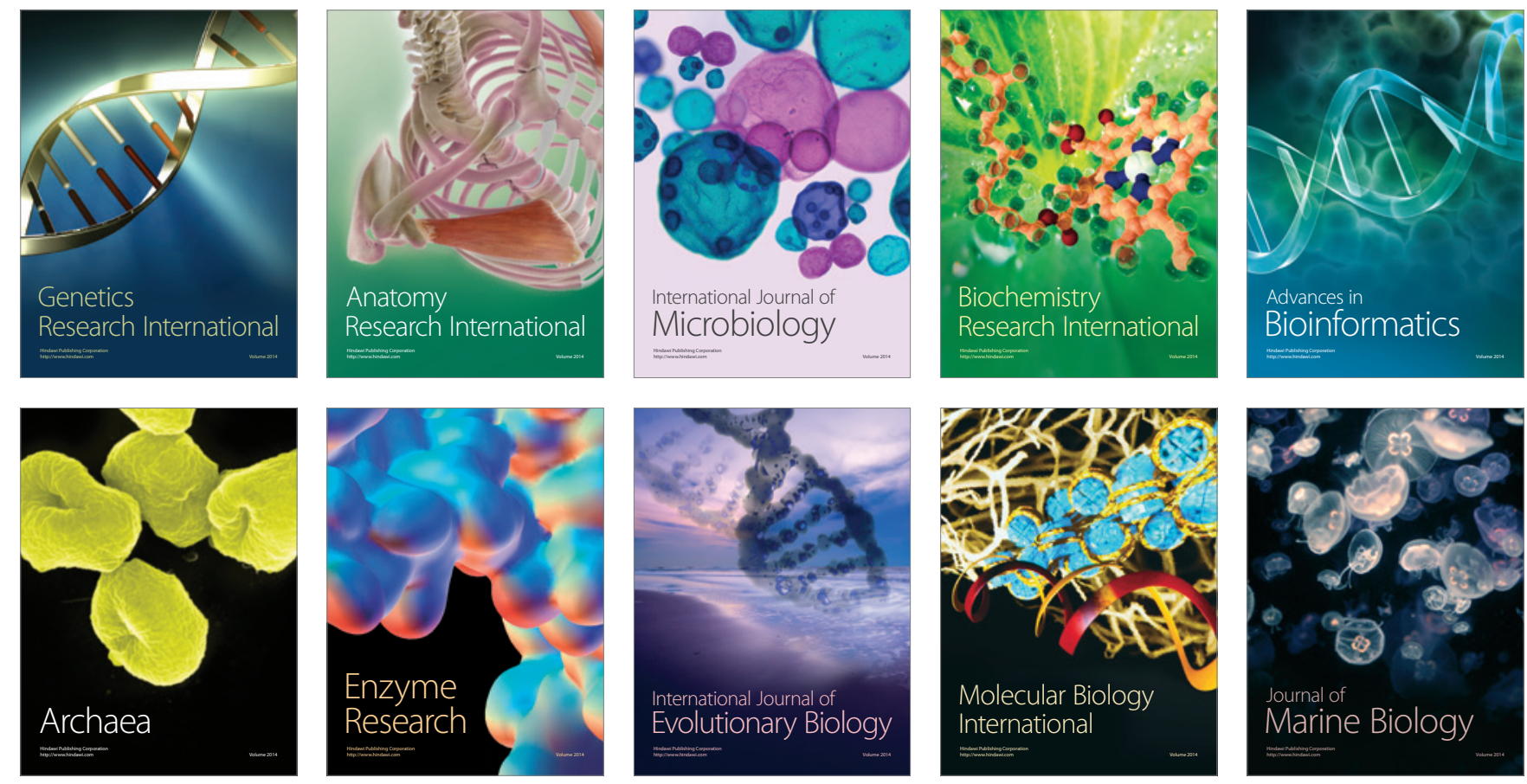